\title{
Arylsulphatase activity and sulphate content in relation to crop rotation and fertilization of soil
}

\author{
Anetta Siwik-Ziomek*, Joanna Lemanowicz, and Jan Koper \\ Sub-Department of Biochemistry, Department of Soil Science and Soil Protection, UTP University of Science and Technology, \\ Bernardyńska 6, 85-129 Bydgoszcz, Poland
}

Received November 17, 2015; accepted June 6, 2016

\begin{abstract}
A b s tract. The aim of the study was to investigate the effect of varying rates of FYM $\left(0,20,40,60 \mathrm{Mg} \mathrm{ha}^{-1}\right)$ and nitrogen $\mathrm{N}_{0}$, $\mathrm{N}_{1}, \mathrm{~N}_{2}$, and $\mathrm{N}_{3}$ on the content of sulphate sulphur (VI) and the activity of arylsulphatase, which participates in the transformations of this element in Haplic Luvisol. The study report is based on a long-term field experiment with two different crop rotations: $\mathrm{A}$ - recognized as exhausting the humus from soil and B - recognized as enriching the soil with humus. During the cultivation of the plants, the soil was sampled four times from corn and a red clover cultivar and grass. The FYM fertilization rate for which the highest arylsulphatase activity and the content of sulphates were identified was $60 \mathrm{Mg} \mathrm{ha}^{-1}$. An inhibitory effect of high rates ( 90 and $135 \mathrm{~kg} \mathrm{~N} \mathrm{ha}^{-1}$ ) of ammonium nitrate on the arylsulphatase activity was also observed. A significant correlation between the content of carbon, nitrogen, and sulphates and the arylsulphatase activity was recorded. The investigation on the effect of combined application of farmyard manure and mineral nitrogen fertilization on the activity of arylsulphatase participating in the sulphur cycling was launched to examine the problem in detail.

K e y w o r d s: arylsulphatase, sulphate sulphur(VI), Luvisol, FYM, nitrogen fertilization
\end{abstract}

\section{INTRODUCTION}

Cultivation practices, such as fertilization, application of farmyard manure and crop rotation affect differently carbon, nitrogen, phosphorus and sulphur cycling in soils (Acosta-Martinez et al., 2011; Dodor and Tabatabai, 2003). Applying organic supplements, such as manure, to agrosystems as a nutrient source in management practice can increase soil organic matter (SOM) and improve the nutrient status in the soil (Mikha and Rice, 2004). Nutrient cycling is essential for the transformation of nutrients into plant

*Corresponding author e-mail: ziomek@utp.edu.pl available forms. The influence of manure application occurs due to the changes in soil microbial communities (AcostaMartinez and Harmel, 2006), strongly affecting the soil potential for enzyme-mediated substrate catalysis that control soil nutrient availability and SOM quality and quantity (Acosta-Martinez et al., 2011). According to Eivazzi et al. (2003), more often enzyme activities increased more often when organic and inorganic fertilizers were added together. Mineral nitrogen can directly affect the microbial production of soil enzymes but the effect varies with the type of soil and enzyme as well as the kind of enzymatic reaction (Iyyemperumal and Shi, 2008). According to the review by Alvarez (2005), nitrogen addition generally results in an increase in the SOM level but only when crop residues are returned to soil. Liu et al. (2010) reported a decrease in soil microbial biomass after the addition of mineral nitrogen.

Over the last two decades, sulphur deficiency has been recognized as a constraint on crop production all over the world (Scherer, 2009; Yang et al., 2007; Zhao et al., 2003), mostly due to the reduction of sulphur dioxide emissions from power plants and other industrial sources (Lehmann et al., 2008), the increasing use of low-S-containing fertilizers, the decreasing use of S-containing fungicides and pesticides and high-yielding crops (Eriksen et al., 2004; Kost et al., 2008; Scherer, 2009). The bioavailability of organic and inorganic sulphur in soils can be controlled through enzyme activities (Scherer, 2009; Tabatabai, 1994). Arylsulphatase (EC 3.1.6.1) is an enzyme that hydrolyzes aromatic sulphate esters ( $\mathrm{R}-\mathrm{O}-\mathrm{SO}_{3}{ }^{2-}$ ) into phenols $(\mathrm{R}-\mathrm{OH})$ and inorganic sulphate $\left(\mathrm{SO}_{4}{ }^{2-}\right)$ (Tabatabai, 1994). These

(C) 2016 Institute of Agrophysics, Polish Academy of Sciences 
enzymes are commonly present in soil and are believed to contribute to the provision of sulphur nutrition to plants (Elsgard and Vinter, 2004). The knowledge of the activity of soil enzymes and the cycle of field-grown plant roots is essential.

Long-term experiments can provide insights into the response of soils to management. However, the impact of long-term simultaneous fertilization with farmyard manure and ammonium nitrate on the arylsulphatase activity in crop rotation species is not well understood. Knauf et al. (2003) investigated the arylsulphatase activity within the rhizosphere of Sinapis album, Lolium perenne, Triticum aestivum and Brassica napus, which were fertilized using organic and mineral fertilizers. The inclusion of a leguminous crop in the crop rotation increases soil enzymatic activity since leguminous crops may secrete higher amounts of exudates into the rhizosphere than non-leguminous crops (Sainju et al., 2006). Therefore, in the present investigations, arylsulphatase activity was determined in soil with two crop rotations: exhausting the soil from organic matter and crop rotation enriching the soil with humus in a longterm field experiment.

The aim of the present research was to determine the effect of selected plants and fertilization with various rates of FYM and ammonium nitrate on the content of available sulphur and the activity of the enzyme that participates in the transformations of sulphur compounds in soil. The variety of root systems among plant species leads to the variation in nutrient uptake and losses and, hence, possibly to changes in the soil microbial activity. We hypothesized that: - the arylsulphatase activity and the content of sulphates

(VI) will change with increasing rates of ammonium nitrate application;

- the content of sulphates (VI) and arylsulphatase will increase with increasing FYM rates;

- the content of carbon, nitrogen, and sulphur will increase due to the cultivation of corn and the red clover and grass plants, and

- there will be a significant relationship between the parameters studied.

\section{MATERIAL AND METHODS}

The research material was sampled from a long term field experiment located in the area of the Agricultural Experiment Station at Grabów, Mazowieckie Province, Zwoleński County, Przyłęki Commune. The location of the experiment station is as follows: altitude $\left(51^{\circ} 21^{\prime} 8^{\prime \prime} \mathrm{N}\right)$, longitude $\left(21^{\circ} 40^{\prime} 8^{\prime \prime} \mathrm{E}\right)$, with lowland climate of moderate altitudes. The experiment was established in 1980 by the Department of Plant Nutrition and Fertilization, the Institute of Soil Science and Plant Cultivation (IUNG) in Puławy. The soils of the Agricultural Experiment Station at Grabów represent Haplic Luvisols (LVh), class IV a, agricultural land and very good rye soil.
The analysis of the granulometric composition (sand fraction $2.0-05 \mathrm{~mm} 61-84 \%$, silt fraction $0.05-0.002$ $15-34 \%$ and clay fraction $<0.0022-7 \%$ ) demonstrated that the soil in the study area shows a loamy sand texture.

The experiment was carried out in a four-year crop rotation design; it was set up using the split-plot method in which the first factor was the type of the crop rotation: A - recognized as exhausting the humus from soil (potato, winter wheat, spring barley, corn grown for silage) and B - recognized as enriching the soil with humus: (potato, winter wheat with white mustard, spring barley with undersown grass, a red clover cultivar with meadow fescue). Four $40 \mathrm{~m}^{2}$ replications of the cultivated plots were created.

The second factor was farmyard manure (FYM) fertilization. FYM was applied in October 2004 at the following rates: $0,20,40$, and $60 \mathrm{Mg} \mathrm{ha}^{-1}$. The chemical composition of fresh cattle FYM applied in the experiment nutrient was as follows: dry matter $21 \mathrm{mg} \mathrm{kg}^{-1}$, total organic carbon (TOC) $81 \mathrm{mg} \mathrm{kg}^{-1}$, nitrogen (N) $4.5 \mathrm{mg} \mathrm{kg}^{-1}$, phosphorus (P) $1.22 \mathrm{mg} \mathrm{kg}^{-1}$, potassium (K) $5.56 \mathrm{mg} \mathrm{kg}^{-1}$, calcium (Ca) $3.0 \mathrm{mg} \mathrm{kg}^{-1}$, magnesium $(\mathrm{Mg}) 0.84 \mathrm{mg} \mathrm{kg}^{-1}$, and sodium (Na) $1.0 \mathrm{mg} \mathrm{kg}^{-1}$. The third factor included nitrogen added in the form of ammonium nitrate $(34 \% \mathrm{~N})$ at the rates of $\mathrm{N}_{0}, \mathrm{~N}_{1}, \mathrm{~N}_{2}$, and $\mathrm{N}_{3}$, where the rate of $\mathrm{N}_{2}$ was an adequate multiplication of the rate of $\mathrm{N}_{1}$. The following rates of $\mathrm{N}_{1}$ in $\mathrm{kg} \mathrm{ha}^{-1} \mathrm{~N}$ in crop rotation A were applied: $\mathrm{N}_{1}: 45 \mathrm{~kg}$ under potato and corn and $40 \mathrm{~kg}$ under winter wheat and spring barley. In crop rotation $\mathrm{B}: \mathrm{N}_{1}: 45 \mathrm{~kg}$ under potato, $40 \mathrm{~kg}$ under winter wheat with mustard and the red clover cultivar with meadow fescue, $30 \mathrm{~kg}$ under spring barley with undersown crops as well as combined for three cuts $120 \mathrm{~kg}$ ( $3 \times 40 \mathrm{~kg}$ each). The next doses of $\mathrm{N}$ were established for $\mathrm{N}_{2}: 90 \mathrm{~kg} \mathrm{~N}$ under potato and corn, $80 \mathrm{~kg} \mathrm{~N}$ under winter wheat, spring barley and red clover + grasses, $60 \mathrm{~kg} \mathrm{~N}$ under spring barley with undersown crops and $\mathrm{N}_{3}: 135 \mathrm{~kg} \mathrm{~N}$ under potato and corn, $120 \mathrm{~kg} \mathrm{~N}$ under winter wheat, spring barley, and red clover + grasses, $90 \mathrm{~kg} \mathrm{~N}$ under spring barley with undersown crops. During a single rotation, 170 $\mathrm{kg} \mathrm{N}$ in both rotations with mineral fertilizers was applied into the soil in plots $\mathrm{N}_{1}$. Phosphorus fertilizers (granulated triplesuperphosphate $20 \% \mathrm{P}$ ) and potassium fertilizers $(50 \% \mathrm{~K})$ were used at the same doses in all the experimental treatments: potato: $24 \mathrm{~kg} \mathrm{ha}^{-1}$ of $\mathrm{P}, 100 \mathrm{~kg} \mathrm{ha}^{-1}$ of $\mathrm{K}$, winter wheat: $21 \mathrm{~kg} \mathrm{ha}^{-1}$ of P, $60 \mathrm{~kg} \mathrm{ha}^{-1}$ of K; spring barley: $24 \mathrm{~kg} \mathrm{ha}^{-1}$ of P, $72 \mathrm{~kg} \mathrm{ha}^{-1}$ of K; corn: $24 \mathrm{~kg} \mathrm{ha}^{-1}$ of P, $132 \mathrm{~kg}$ $\mathrm{ha}^{-1}$ of K ; and red clover: $24 \mathrm{~kg} \mathrm{ha}^{-1}$ of P, $100 \mathrm{~kg} \mathrm{ha}^{-1}$ of K.

The soil was sampled four times under corn and the mixture of clover and grasses during the vegetation period in April, June, July, and September in 2008. The weather conditions were extremely diverse (Table 1 ). The vegetation of plants was recorded in the third week of March. The fairly balanced distribution of precipitation during the vegetable period was favourable for the plants. There were relatively low temperatures including frost in mid-May, which resulted in some plant freezing. June was characterized 
T a b l e 1. Air temperature $\left({ }^{\circ} \mathrm{C}\right)$ and rainfall $(\mathrm{mm})$ during the vegetation period

\begin{tabular}{lccccccc}
\hline \multirow{2}{*}{ Specification } & \multicolumn{7}{c}{ Months } \\
\cline { 2 - 7 } & IV & V & VI & VII & VIII & IX & IV-IX \\
\hline Air temperature $\left({ }^{\circ} \mathrm{C}\right)$ & 8.2 & 12.0 & 15.9 & 18.0 & 18.6 & 13.0 & 14.3 \\
Rainfall $(\mathrm{mm})$ & 67.0 & 41.3 & 83.7 & 112.1 & 58.7 & 17.5 & 380 \\
\hline
\end{tabular}

by low temperatures and only in July, along with higher temperatures and significant rainfall, rapid growth and the development of plants was recorded.

Soil samples were sieved to pass through a $2 \mathrm{~mm}$ sieve. Arylsulphatase activity was determined according to the method of Tabatabai (1994). The soil samples (1.0 g)

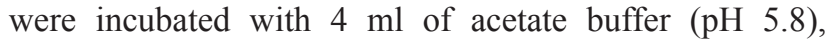
$125 \mu \mathrm{l}$ of toluene, and $1 \mathrm{ml}$ of a potassium p-nitrophenyl sulphate solution at $37^{\circ} \mathrm{C}$ for $1 \mathrm{~h}$. Afterwards, $0.5 \mathrm{M} \mathrm{CaCl}_{2}$ and $4 \mathrm{ml} 0.5 \mathrm{M} \mathrm{NaOH}$ were added and then the solution was filtered. The intensity of the colour of the p-nitrophenol formed was determined by reading the absorbance at $420 \mathrm{~nm}$ using a calibration absorbance curve versus the p-nitrophenol concentrations. The content of sulphate sulphur was determined according to the Bardsley-Lancaster turbidimetric method (1960) as modified by COMN-IUNG using a UV-visible spectrophotometer Evolution 201. The following parameters were also analysed in the soil material: 1. $\mathrm{pH}$ in $\mathrm{KCl}$, 2. organic carbon with the TOC Primacs analyser by Scalar, and 3. total nitrogen was determined using the Kjeldahl method (PN-ISO 11261, 2002).

All the assays were made in three replicates. The paper presents mean arithmetic values. The results were subjected to the analysis of variance and the significance of the differences between the mean values was verified using the Tukey test at $\mathrm{p}=0.05$. All the calculations were performed using FR-ANALWAR software based on Microsoft Excel.

T a b l e 2. Total organic carbon and total nitrogen content
The results of the analyses were also exposed to the analysis of simple correlation using Statistica for Windows $\mathrm{Pl}$ software $(\mathrm{R}=8$ treatments $\times 2$ replications $\times 2$ crop species $\times 4$ times $=64$ objects for one crop rotation).

\section{RESULTS AND DISCUSSION}

Optimal balanced crop rotation involving forage legumes can improve the organic carbon status in the soil. Soon et al. (2007), who tested the influence of 12 years of four crop sequences on the organic $\mathrm{C}$ pools in a Grey Luvisolic sandy loam soil, found increased total organic $\mathrm{C}$ content in the top $15 \mathrm{~cm}$ of soil in the red clover rotation compared with pea. It was demonstrated that the farming practices led to changes in the SOM content. These changes are difficult to detect over a short or medium time; thus, the content of total organic carbon (TOC) in the soil from Grabów was not related to the plant grown (Table 2). In our study, fertilization exerted a crucial impact on the content of TOC. Irrespective of the rates of FYM and nitrogen fertilizer applied, a higher content of TOC was found in the soil sampled from the plots at the rates of 40 and $60 \mathrm{Mg} \mathrm{ha}^{-1}$ of FYM. The effect of the high $\left(\mathrm{N}_{2}\right.$ and $\left.\mathrm{N}_{3}\right)$ rates of ammonium nitrate, on the other hand, decreased the content of organic carbon in the samples, compared with the control objects. The increase in SOC due to organic amendments can be substantial. Results from a Rothamsted long-term agricultural experiment in Great Britain showed that continuous

\begin{tabular}{cccc}
\hline Specification & & $\mathrm{TOC} \mathrm{g} \mathrm{kg}^{-1}$ & $\mathrm{TN} \mathrm{g} \mathrm{kg}^{-1}$ \\
\hline Crop rotation & $\mathrm{A}$ & $9.802 \mathrm{a}$ & $0.976 \mathrm{a}$ \\
\cline { 2 - 4 } I factor & $\mathrm{B}$ & $10.59 \mathrm{a}$ & $1.088 \mathrm{~b}$ \\
\hline & 0 & $8.599 \mathrm{a}$ & $0.872 \mathrm{a}$ \\
FYM t ha-1 II factor & 20 & $10.015 \mathrm{~b}$ & $1.062 \mathrm{~b}$ \\
& 40 & $10.826 \mathrm{c}$ & $1.071 \mathrm{~b}$ \\
& 60 & $11.348 \mathrm{c}$ & $1.123 \mathrm{c}$ \\
Nitrogen kg kg & & $10.538 \mathrm{~b}$ & $0.964 \mathrm{a}$ \\
III factor & $\mathrm{N}_{0}$ & $10.556 \mathrm{~b}$ & $1.038 \mathrm{~b}$ \\
& $\mathrm{~N}^{-1}$ & $9.971 \mathrm{a}$ & $1.063 \mathrm{c}$ \\
Mean & $\mathrm{N}_{2}$ & $9.723 \mathrm{a}$ & $1.061 \mathrm{c}$ \\
SD & $\mathrm{N}_{3}$ & 10.2 & 1.03 \\
& & 1.37 & 0.13 \\
\hline
\end{tabular}

$\mathrm{A}, \mathrm{B}-$ crop rotation, $\mathrm{SD}$ - standard deviation, $\mathrm{a}, \mathrm{b}-$ values differ significantly at $\mathrm{p}<0.05$. 
application of farmyard manure almost tripled the SOC content over 100 years (McLauchlan, 2006). Melero et al. (2006) reported that organic management maintained soil organic matter at higher levels than inorganic fertilization.

The content of total nitrogen (TN) was related to the plant species applied (Table 2). The higher amount of mineral nitrogen was found in the soil from the crop rotation with the mixture of clover and grasses. Similar results were reported by Pecio et al. (2005) for a four-field crop rotation design, in which corn for grain, spring barley, oat, and winter wheat were grown. The effect of crop rotation on the nitrogen content in the soil was also confirmed by Melero et al. (2011), reporting the lowest soil nitrate content in wheat-sunflower rotation and the highest in the wheat-faba bean rotation. The lowest content of total nitrogen was determined in the soil sampled from the objects without FYM fertilization (Table 2). The difference between the $\mathrm{N}$ content in the soils from the control objects and fertilization with $60 \mathrm{Mg} \mathrm{ha}^{-1} 4$ year $^{-1} \mathrm{FYM}$ was $22 \%$. In turn, a significant increase in soil $\mathrm{N}$ to $68 \%$ was reported by Nett et al. (2011), comparing the non-fertilized treatment with the fertilization rate of $60 \mathrm{Mg}$ FYM ha ${ }^{-1}$ year $^{-1}$. The FYM was applied on loamy sand every year since 1989 . The application of increasing rates of nitrogen fertilizers increased the content of mineral nitrogen in soil. Melero et al. (2011), on the other hand, reported that nitrogen fertilization $(\mathrm{N}$ rate: 50 and $\left.150 \mathrm{~kg} \mathrm{~N} \mathrm{ha}^{-1}\right)$ had no great effect on nitrate content in the upper layers $(0-10 \mathrm{~cm}$ depth).

The ratio of $\mathrm{C}: \mathrm{N}$ in the soil under corn ranged from 9.1 to 11.8 ; however, it declined within the range from 8.0 to 14.5 for clover and grasses (Table 3 ). The crop rotation with the plants that 'enrich' soil with organic matter widened the ratio of $\mathrm{C}: \mathrm{N}$ crop, which can affect the biological activity in soil, mostly through the increase in the population of microorganisms that can easily use both components. Soil microorganisms that transform organic and mineral compounds enrich the soil with nitrogen, promote plant growth, and deliver antibiotic and biologically active substances; a substantial role in these transformations is played by enzymatic processes (Janvier et al., 2007). One can thus assume that the arylsulphatase activity in crop rotation with a mixture of clover and grasses is of microbiological origin.

Based on the analysis of active and exchangeable acidity, it was found that the soil represents acid and slightly acid soils (Table 3). A lower $\mathrm{pH}$ value was observed in the soil sampled from the plots with the mixture of clover and grasses. The soil $\mathrm{pH}$ affects the activity of enzymes and the content of sulphates available to plants (Gianfreda and Ruggiero, 2006; Scherer, 2009). The prevailing form of sulphur in soil is organic sulphur and the content of the mineral forms available to plants is related to the intensity of mineralization of plant residues, organic fertilizers, and humus. The transformations of organic sulphur into its mineral forms are enhanced by high $\mathrm{pH}$. An increase in this parameter to $\mathrm{pH} 7.5$ increases the mineralization rate. In soils with $\mathrm{pH}$ above 6.0, sulphate sulphur occurs in the soil solution and is easily available to plants (Scherer, 2009).

Arylsulphatase activity depends on the type of crop, FYM, and ammonium nitrate fertilization (Table 4). Irrespective of the plant, the highest activity of the enzyme was found in the soil sampled at the beginning and at the end of the vegetation period (Table 4). The seasonal decrease in the activity of hydrolase may be due to a change in soil moisture and temperature increase (Table 1). Thus,

T a b l e 3. Value of $\mathrm{C}: \mathrm{N}$ and $\mathrm{pH}$ in $\mathrm{H}_{2} \mathrm{O}$ and $\mathrm{KCl}$

\begin{tabular}{|c|c|c|c|c|c|c|c|c|c|c|c|c|}
\hline \multirow{3}{*}{$\begin{array}{l}\text { FYM } \\
\text { t ha }^{-1}\end{array}$} & \multicolumn{4}{|c|}{$\mathrm{C}: \mathrm{N}$} & \multicolumn{4}{|c|}{$\mathrm{pH}$ in $\mathrm{H}_{2} \mathrm{O}$} & \multicolumn{4}{|c|}{$\mathrm{pH}$ in $\mathrm{KCl}$} \\
\hline & \multirow[b]{2}{*}{$\mathrm{N}_{0}$} & \multirow[b]{2}{*}{$\mathrm{N}_{1}$} & \multirow[b]{2}{*}{$\mathrm{N}_{2}$} & \multirow[b]{2}{*}{$\mathrm{N}_{3}$} & \multicolumn{4}{|c|}{ Rates of nitrogen } & \multirow[b]{2}{*}{$\mathrm{N}_{0}$} & \multirow[b]{2}{*}{$\mathrm{N}_{1}$} & \multirow[b]{2}{*}{$\mathrm{N}_{2}$} & \multirow[b]{2}{*}{$\mathrm{N}_{3}$} \\
\hline & & & & & $\mathrm{N}_{0}$ & $\mathrm{~N}_{1}$ & $\mathrm{~N}_{2}$ & $\mathrm{~N}_{3}$ & & & & \\
\hline \multicolumn{13}{|c|}{ Crop rotation A } \\
\hline 0 & 10.9 & 10.6 & 9.4 & 10.1 & 6.2 & 6.0 & 6.0 & 5.9 & 5.8 & 5.7 & 5.5 & 5.3 \\
\hline 20 & 11.8 & 11.7 & 8.4 & 9.6 & 6.0 & 5.8 & 5.9 & 5.8 & 5.3 & 5.4 & 5.4 & 5.3 \\
\hline 40 & 10.8 & 11.0 & 8.6 & 9.1 & 5.9 & 5.9 & 5.8 & 5.8 & 5.4 & 5.4 & 5.4 & 5.2 \\
\hline 60 & 11.2 & 9.6 & 9.2 & 9.5 & 5.9 & 5.9 & 5.9 & 5.8 & 5.4 & 5.5 & 5.5 & 5.3 \\
\hline \multicolumn{13}{|c|}{ Crop rotation B } \\
\hline 0 & 10.4 & 8.6 & 10.1 & 9.1 & 5.6 & 5.9 & 5.6 & 5.4 & 4.9 & 4.7 & 4.8 & 4.8 \\
\hline 20 & 9.3 & 8.6 & 8.7 & 8.2 & 5.6 & 5.4 & 5.5 & 5.4 & 5.0 & 4.9 & 4.9 & 4.9 \\
\hline 40 & 14.5 & 10.4 & 9.8 & 8.0 & 5.7 & 5.6 & 5.7 & 5.6 & 5.0 & 5.0 & 5.0 & 5.0 \\
\hline 60 & 9.6 & 11.1 & 10.7 & 10.1 & 5.7 & 5.6 & 5.6 & 5.7 & 5.3 & 5.2 & 5.1 & 5.2 \\
\hline
\end{tabular}


T a b l e 4. Dynamics of arylsulphatase activity in soil depending on the crop rotation, rates of FYM and ammonium nitrate

\begin{tabular}{|c|c|c|c|c|c|c|}
\hline \multirow{2}{*}{ Properties } & \multicolumn{6}{|c|}{ Arylsulphatase activity $\mathrm{mM} \mathrm{pNP} \mathrm{kg}^{-1} \mathrm{~h}^{-1}$} \\
\hline & & April & June & July & September & Mean \\
\hline Crop rotation & $\mathrm{A}$ & $0.278 \mathrm{a}$ & $0.199 \mathrm{a}$ & $0.183 \mathrm{a}$ & $0.308 \mathrm{a}$ & 0.445 \\
\hline I factor & $\mathrm{B}$ & $0.380 \mathrm{~b}$ & $0.294 \mathrm{~b}$ & $0.259 \mathrm{~b}$ & $0.366 \mathrm{~b}$ & 0.535 \\
\hline FYM & 0 & $0.253 \mathrm{a}$ & $0.174 \mathrm{a}$ & $0.139 \mathrm{a}$ & $0.367 \mathrm{ab}$ & 0.433 \\
\hline $\mathrm{t} \mathrm{ha}^{-1}$ & 20 & $0.317 \mathrm{~b}$ & $0.246 \mathrm{~b}$ & $0.191 \mathrm{~b}$ & $0.298 \mathrm{a}$ & 0.450 \\
\hline \multirow[t]{2}{*}{ II factor } & 40 & $0.337 \mathrm{~b}$ & $0.253 \mathrm{~b}$ & $0.243 \mathrm{c}$ & $0.290 \mathrm{a}$ & 0.471 \\
\hline & 60 & $0.409 \mathrm{c}$ & $0.314 \mathrm{c}$ & $0.312 \mathrm{~d}$ & $0.395 \mathrm{~b}$ & 0.609 \\
\hline Nitrogen & $\mathrm{N}_{0}$ & $0.339 \mathrm{ab}$ & $0.261 \mathrm{c}$ & $0.239 \mathrm{~b}$ & $0.433 \mathrm{~b}$ & 0.568 \\
\hline $\mathrm{kg} \mathrm{kg}^{-1}$ & $\mathrm{~N}_{1}^{0}$ & $0.305 \mathrm{a}$ & $0.274 \mathrm{~d}$ & $0.232 \mathrm{~b}$ & $0.316 \mathrm{a}$ & 0.481 \\
\hline \multirow[t]{2}{*}{ III factor } & $\mathrm{N}_{2}$ & $0.334 \mathrm{a}$ & $0.232 \mathrm{~b}$ & $0.216 \mathrm{a}$ & $0.304 \mathrm{a}$ & 0.463 \\
\hline & $\mathrm{N}_{3}^{2}$ & $0.337 \mathrm{ab}$ & $0.219 \mathrm{a}$ & $0.196 \mathrm{a}$ & $0.296 \mathrm{a}$ & 0.448 \\
\hline Mean & & 0.329 & 0.247 & 0.221 & 0.338 & 0.491 \\
\hline SD & & 0.100 & 0.098 & 0.101 & 0.256 & \\
\hline
\end{tabular}

0, 20, 40, 60 - rates of FYM tha-1 $\mathrm{N}_{0}, \mathrm{~N}_{1}, \mathrm{~N}_{2}, \mathrm{~N}_{3}$ - rates of ammonium nitrate. Other explanations as in Table 2.

environmental conditions inhibited the activity of soil microorganisms in the soils. The soil moisture content changes over time, and therefore the distribution of soil enzymes and decomposition rates are probably highly dynamic (Baldrian, 2014).

A significant effect of the type of plants on the arylsulphatase activity in the Luvisol under study was recorded. The activity of the enzyme ranged from $0.174 \mathrm{mM}$ pNP $\mathrm{kg}^{-1} \mathrm{~h}^{-1}$ to $0.433 \mathrm{mM} \mathrm{pNP} \mathrm{kg}{ }^{-1} \mathrm{~h}^{-1}$ (Table 4). A higher activity of arylsulphatase was recorded in the soil sampled from the crop rotation that included clover (Table 4). The type of crop can affect soil enzyme activities. Generally, a monoculture causes physical soil degradation with possible negative effects on soil microbial properties, whereas crop rotation enhances the microbial activity of soil. The high input and diversity of organic materials stimulate microbial activity, leading to higher concentrations of microbial biomass and enzyme activities than monocropping systems (Dodor and Tabatabai, 2003). Other factors that affect enzyme activity are the crop type and the root system due to the rhizosphere effect (Gianfreda and Ruggiero, 2006). As reported by Knauff et al. (2003), the highest activities of arylsulphatase from a long-term field experiment were found within the rhizosphere of Brassica napus and Triticum aestivum, and the lowest values in the case of Sinapus album and Lolium perenne. Plants actively respond to an insufficient sulphur supply by producing and excreting sulphatases, which may help them to exploit the organic soil sulphur compounds. The activities are relatively low, but they may increase with more severe S deficiency. Knauff et al. (2003) assumed that arylsulphatase activity determined in roots of sterilegrown plants is derived from endophytic bacteria and not by higher plants.
The application of farmyard manure in the experiment increased the arylsulphatase activity (Table 4). Usually, an increase in the FYM rate increased the hydrolase activity. The long-term effect of organic amendments on enzyme activities is probably a combined effect of a higher degree of stabilization of enzymes to humic substances and an increase in microbial biomass with increased soil carbon concentration (Elfstrand et al., 2007). The optimal FYM rate for which the highest arylsulphatase activity in soil was observed for each of the soil sampling dates was $60 \mathrm{Mg} \mathrm{ha}^{-1}$ (Table 4). In general, the addition of organic residues can stimulate enzyme activities as a result of microbial proliferation or enzyme induction in response to addition of inhibitors, such as heavy metals, not present in the organic residue (Gianfreda and Ruggiero, 2006). Eivazi et al. (2003) reported that the ratios between enzymes such as acid phosphatase and alkaline phosphatase activities as well as urease and arylsulphatase activity were significantly higher after the application of manure, regardless of the crop type. Knauff et al. (2003) also reported that arylsulphatase activity was correlated with the amount of organic carbon and can be increased by long-term amendment of organic manure. Similar results were reported by Elfstrand et al. (2007), ie the protease and arylsulphatase activities in soil with FYM were significantly higher than in green manure and sawdust treatments. In contrast, Liang et al. (2014) detected no significant difference in arylsulphatase activity among three fertilization schemes: control without fertilization, mineral fertilization, and FYM treatments in a long-term fertilizer experiment started in 1993. 
T a b l e 5. Dynamics of sulphate sulphur $\left(\mathrm{S}_{-} \mathrm{SO}_{4}^{2-}\right)$ content in soil depending on the crop rotation, rates of FYM and ammonium nitrate

\begin{tabular}{|c|c|c|c|c|c|c|}
\hline \multirow{2}{*}{ Properties } & \multicolumn{6}{|c|}{$\mathrm{S}_{-} \mathrm{SO}_{4}{ }^{2-} \mathrm{mg} \mathrm{kg}^{-1}$} \\
\hline & & April & June & July & September & Mean \\
\hline Crop rotation & A & $12.912 \mathrm{a}$ & $13.792 b$ & $16.865 b$ & $15.033 b$ & 14.650 \\
\hline I factor & B & $10.411 \mathrm{a}$ & $10.221 \mathrm{a}$ & $9.818 \mathrm{a}$ & $9.963 \mathrm{a}$ & 10.103 \\
\hline FYM & 0 & $8.053 \mathrm{a}$ & $10.788 \mathrm{a}$ & $12.562 b$ & $10.016 \mathrm{a}$ & 10.355 \\
\hline $\mathrm{tha}^{-1}$ & 20 & $10.374 b$ & $12.440 \mathrm{c}$ & $11.052 \mathrm{a}$ & $10.474 \mathrm{a}$ & 11.085 \\
\hline \multirow[t]{2}{*}{ II factor } & 40 & $14.473 \mathrm{~cd}$ & $12.838 \mathrm{c}$ & $13.149 \mathrm{c}$ & $13.194 b$ & 13.413 \\
\hline & 60 & $13.746 \mathrm{c}$ & $11.960 \mathrm{~b}$ & $16.602 d$ & $16.309 \mathrm{c}$ & 14.654 \\
\hline Nitrogen & $\mathrm{N}_{0}$ & $13.393 c$ & $11.941 \mathrm{a}$ & $13.321 \mathrm{ab}$ & $12.445 b$ & 12.775 \\
\hline $\mathrm{kg} \mathrm{kg}^{-1}$ & $\mathrm{~N}_{1}^{0}$ & $10.276 \mathrm{a}$ & $12.213 b$ & $12.446 a$ & $11.789 a$ & 11.681 \\
\hline \multirow[t]{2}{*}{ III factor } & $\mathrm{N}_{2}^{1}$ & $11.599 \mathrm{ab}$ & $11.500 \mathrm{a}$ & $12.675 \mathrm{a}$ & $13.096 \mathrm{c}$ & 12.217 \\
\hline & $\mathrm{N}_{3}^{2}$ & $11.377 \mathrm{a}$ & $12.373 b$ & $14.922 \mathrm{c}$ & $12.663 b$ & 12.833 \\
\hline Mean & & 11.662 & 12.007 & 13.342 & 12.498 & 12.377 \\
\hline SD & & 4.763 & 2.202 & 4.826 & 3.997 & \\
\hline
\end{tabular}

Explanation as in Tables 2 and 4.

T a b l e 6. Correlation matrix between the chemical properties and arylsulphatase activity $(n=64)$

\begin{tabular}{|c|c|c|c|c|c|c|}
\hline Crop rotation & & TOC & $\mathrm{TN}$ & $\mathrm{pH}_{\mathrm{KCl}}$ & $\mathrm{pH}_{\mathrm{H}_{2} \mathrm{O}}$ & $\mathrm{S}-\mathrm{SO}_{4}^{2-}$ \\
\hline \multirow[t]{2}{*}{$\mathrm{A}$} & $\mathrm{S}-\mathrm{SO}_{4}^{2-}$ & 0.27 & 0.39 & -0.21 & -0.24 & - \\
\hline & Arylsulphatase & 0.43 & 0.44 & - & - & n.s. \\
\hline \multirow[t]{2}{*}{ B } & $\mathrm{S}-\mathrm{SO}_{4}^{2-}$ & 0.62 & 0.54 & -0.30 & -0.30 & - \\
\hline & Arylsulphatase & 0.58 & 0.47 & n.s. & n.s. & 0.62 \\
\hline
\end{tabular}

TOC - total organic carbon, TN - total nitrogen, n.s - differences not significant, significant at $\mathrm{p}<0.0$.

Fertilization with ammonium nitrate also affected the activity of arylsulphatase. Usually, the highest activity of this enzyme was recorded in the soil from the plots fertilized with the lowest rate of the nitrogen fertilizer. This was especially true in the soil sampled in the case of the last two dates, in which the arylsulphatase activity from the plots with a fertilizer rate of $\mathrm{N}_{0}$ was by 18 and $32 \%$ higher than in the soil from the plots with the highest rate of ammonium nitrate, respectively (Table 4). Nitrogen fertilization, especially in mineral forms, may have an indirect impact on the activities of soil enzymes via changes in soil properties such as pH (Gianfreda and Ruggiero, 2006). Enzyme activities increased more often when organic and mineral nitrogen fertilizers were added together (Eivazi et al., 2003). Zhang et al. (2015) reported that long-term $\mathrm{N}$ fertilization decreased soil $\alpha$ - and $\beta$ - glucosidase activities. This can be explained by the fact that salts tend to modify the ionic conformation of the active centre of enzymes; specific ion toxicities can also result in nutritional imbalances for microbial growth and subsequent enzyme synthesis.

The present research has demonstrated that the effect on the content of sulphur (VI) depends on crop rotation, term of sampling, and plant fertilization (Table 5). The con- tent of sulphates in the soil ranged from $12.912 \mathrm{mg} \mathrm{kg}^{-1}$ to $16.865 \mathrm{mg} \mathrm{kg}^{-1}$ in the soil sampled from crop rotation A and from 9.818 to $10.411 \mathrm{mg} \mathrm{kg}^{-1}$ in the samples from experiment B (Table 5). In general, in the soils under agricultural use in Poland, the content of $\mathrm{S}_{-} \mathrm{SO}_{4}^{2-}$ does not exceed $25 \mathrm{mg}$ $\mathrm{kg}^{-1}$. Most soils, ie $70 \%$ of the agricultural acreage, contain from 5.0 to $20.0 \mathrm{mg} \mathrm{kg}^{-1}$ of this component (Lipiński et al., 2003). In our study, the content of available sulphur in the soil classifies it as representing a class of soils with medium (10.1-15.0 $\mathrm{mg} \mathrm{kg}^{-1}$ ) and high (15.1-20.0 $\mathrm{mg} \mathrm{kg}^{-1}$ ) content of the component for crop B and for crop A, respectively. The medium content of sulphates (VI) in soil requires supplementation with sulphur. The lowest content of sulphur in available forms was recorded in the soil sampled during the penultimate and the final soil sampling date in crop rotation B (Table 5). Growing a mixture of clover with grasses in the experimental field at Grabów would require an additional use of $15 \mathrm{~kg} \mathrm{~S} \mathrm{ha}^{-1}$ (Lipiński et al., 2003). A concentration of sulphates (VI) in soil below $10 \mathrm{mg} \mathrm{kg}^{-1}$ is considered low and does not ensure that plants have an adequate supply of sulphur. Sulphur (VI) deficit in plant production has become a problem of contemporary agriculture (Eriksen et al., 2004; Scherer, 2009). Sulphur plays 
a dual role in the Fabaceae; it is essential for symbiotic nitrogen fixation and for protein synthesis. When exposed to sulphur deficit, plants produce lower amounts of valuable protein which contains lower levels of indispensable amino acids. Biological nitrogen fixation, nodulation, and yield of peanut crops are reduced with S-deficiency. Varin et al. (2010) examined whether the effect of $\mathrm{SO}_{4}^{2-}$ addition on nitrogen fixation resulted from a stimulation of host plant growth, a specific effect of sulphur on nodulation, or a specific effect of $\mathrm{S}$ on nodule metabolism. The application of sulphate (VI) increased whole plant dry mass, root length, and nodule biomass expressed on a rootlength basis. Nitrogen fixation was drastically reduced in S-deficient plants as a consequence of a low nodule development, but also due to low nitrogenase and leghaemoglobin production due to down-regulation by a nitrogen feedback mechanism, as the high concentration of whole plant nitrogen and the accumulation of N-rich amino acids under severe sulphur deficiency indicated that the assimilation of nitrogen exceeded the amount required for plant growth. Compared with subterranean clover supplied with $\mathrm{S}$, nodulation was markedly decreased in the S-deficient clover. This is attributed to the decline in the requirement for $\mathrm{N}$ with reduced $\mathrm{S}$ supply (Mazid et al., 2011).

In the investigation in Grabów, an influence of the FYM doses on the sulphate (VI) content during plant vegetation was reported. The lowest sulphate content was observed in soil without FYM (exceptionally: July). It was found that the optimal rates of a natural fertilizer for which the highest contents of sulphates in soil were determined were the amounts of 40 and $60 \mathrm{Mg} \mathrm{ha}^{-1}$ (Table 5). Knauff et al. (2003) assumed that the long-term amendments of FYM or compost, respectively, not only increased the organic matter and total sulphur content of soils but also the sulphatase activity; these findings show that agronomic measures such as compost and FYM application improve the availability of soil organic sulphur.

An influence of the mineral nitrogen fertilizer application on the content of available sulphur was observed during the vegetation period of corn and grasses with clover. The interaction between the sulphate (VI) content and the doses of nitrogen from ammonium nitrate was changed. The highest sulphate content in April was noticed in soil without $\mathrm{N}$, but in July with $\mathrm{N}_{3}$. This may be a result of different nitrogen and sulphur requirements of the plants or the varying uptake of these nutrients. This may be also an effect of application of ammonium nitrate, which acidifies the soil and thus contributes to varied rates of sulphur sorption by soil components. Adsorption of $\mathrm{SO}_{4}{ }^{2-}$ is stronger at low soil $\mathrm{pH}$; at $\mathrm{pH}>6.5$, adsorption is negligible and most sulphates are found in the soil solution (Scherer, 2009). Tables 3 and 4 show changes in the content of sulphates as well as the arylsulphatase activity during the vegetation period in both species. It can be noticed that there was higher arylsulphatase activity in the plot with the lower content of available sulphur. Similarly, Speir et al. (1980) found that low $\mathrm{SO}_{4}^{2-}$ concentrations in the soil solution were associated with poor sulphur availability to plants and microorganisms that stimulate the biotic production of sulphohydrolases. Conversely, the synthesis of sulphohydrolases and their activity in soil decrease in the case of lower amounts of sulphates. According to another author (Dick, 1992), the activities of the soil enzymes involved in the cycling of a given nutrient are often negatively associated with the availability of the nutrient in soil.

The present study has presented the effect of other parameters on the content on arylsulphatase activity in soil. Soil organic carbon and nitrogen are the most important soil components that may influence the activities of enzymes in soil since they reflect the amount of organic matter (Gianfreda and Bollag, 1996). The activity of arylsulphatase was positively correlated with the content of total organic carbon $(r=0.43$ for crop rotation A and $r=0.58$ for crop rotation $B p<0.05)$ and total nitrogen $(r=0.44$ for crop rotation $A$ and $r=0.47$ for crop rotation $B$ $\mathrm{p}<0.05$ ) (Table 6 ). Arylsulphatase activity was found to be positively correlated with the content of sulphate sulphur $(\mathrm{r}=0.62$ for crop rotation $\mathrm{B} \mathrm{p}<0.05)$ (Table 6). The activity of this enzyme was negatively correlated with $\mathrm{pH}$ in $1 \mathrm{M} \mathrm{KCl}$. The negative significant correlation confirms the results that have been reported by other authors (Kotkova et al., 2008; Vong et al., 2004). They also observed that high contents of sulphates in soil decrease the activity of arylsulphatase.

\section{CONCLUSIONS}

1. The content of total nitrogen and sulphate sulphur in soil was related to the plant species and the type of fertilization applied. Higher contents of nutrients were recorded in the soil sampled from the crop rotation with mixtures of clover and grasses.

2. The highest activity of arylsulphatase and high content of sulphates in soil were noted in the plot with the farmyard manure rate of $60 \mathrm{Mg} \mathrm{ha}^{-1}$.

3. A varied effect of fertilization with ammonium nitrate on the content of sulphate sulphur and the arylsulphatase activity was recorded. The ambiguous effect of increasing the rates of nitrogen fertilizer may be caused by the acidifying effect of the nitrate fertilizer on soil.

4. The statistical correlation between the organic matter and the content of sulphate sulphur and the arylsulphatase activity indicates a significant relationship between these parameters in soil.

Conflict of interest: The Authors do not declare conflict of interest. 


\section{REFERENCES}

Acosta-Martinez V. and Harmel D.R., 2006. Soil microbial communities and enzyme activities under various poultry litter application rates. J. Environ. Qual., 35, 1009-1318.

Acosta-Martinez V., Mikha M.M., Sistani K.R., Stahlman P.W., Benjamin J.G., Vigil M.F., and Erickson R., 2011. Multi-location study of soil enzyme activities as affected by types and rates of manure application and tillage practices. Agriculture, 1, 4-21.

Alvarez R., 2005. A review of nitrogen fertilizer and conservation tillage effects on soil organic carbon storage. Soil Use Manag., 21(1), 38-52.

Baldrian P., 2014. Distribution of extracellular enzymes in soils: spatial heterogeneity and determining factors at various scales. www.soils.org/publications/sssaj

Bardsley C.E. and Lancaster J.D., 1960. Determination of reserve sulfur and soluble sulfates in soil. Soil Sci. Soc. Am. Proc., 24, 265-268.

Dick R.P., 1992. A review: long-term effects of agricultural system on soil biochemical and microbial parameters. Agr. Ecosyst. Environ., 40, 25-60.

Dodor D.E., and Tabatabai M.A., 2003. Amidohydrolases in soil as affected by cropping systems. Appl. Soil Ecol., 24, 73-90.

Eivazi F., Bayan M.R., and Schmidt K., 2003. Select soil enzyme activities in the historic Sanborn Field as affected by long-term cropping system. Soil Sci. Plant Anal., 34, 2259-2275.

Elfstrand S., Hedlund K., and Martensson A., 2007. Soil enzyme activities, microbial community composition and function after 47 years of continuous green manuring. Appl. Soil Ecol., 35, 610-621.

Elsgard L. and Vinter F.P., 2004. Modeling of the fine-scale temperature response of arylsulfatase activity in soil. J. Plant Nutr. Soil Sci., 167, 196-201.

Eriksen J., Thorup-Kristensen K., and Alskegaard M., 2004. Plant avaibility of catch crop sulphur following spring incorporation. J. Plant Soil Sci., 167, 609-615.

Gianfreda L., and Bollag J.M., 1996. Influence of natural and anthropogenic factors on enzyme 26 activity in soil. In: Soil Biochemistry (Eds G. Stotzky, J.M. Bollag). Marcel Dekker, New York, USA.

Gianfreda L. and Ruggiero P., 2006. Enzyme activities in soil. In: Soil Biology (Eds P. Nannipieri, K. Smalla). SpringerVerlag Berlin Heidelberg, Germany.

Iyyemperumal K. and Shi W., 2008. Soil enzyme activities in two forage system following application of different rates of swine lagoon effluent or ammonium nitrate. App. Soil Ecol., 38, 128-136.

Janvier C., Villeneuve F., Alabouvette C., Edel-Hermann V., Mateille T., and Steinberg C., 2007. Soil health through soil disease suppression: Which strategy from descriptors to indicators? Soil Biol. Bioch., 39, 1-23.

Knauff U., Schulz M., and Scherer H.W., 2003. Arylsulphatase activity in the rhizosphere and roots of different crop species. Eur. J. Agron., 19, 215-223.
Kost D., Chen L., and Dick W.A., 2008. Predicting plant sulfur deficiency in soils: results from Ohio. Biol. Fert. Soils., 44, 1091-1098.

Kotkova B., Balik J., Cerny J., Kulkanek M., and Bazalova M., 2008. Crop influence on mobile sulphur content and arylsulphatase activity in the plant rhizosphere. Plant Soil Environ., 54, 100-107.

Lehmann J., Solomon D., Zhao F.J., and McGrath S.P., 2008. Atmosferic $\mathrm{SO}_{2}$ emission since the late $1800 \mathrm{~s}$ change organic sulphur forms in humic substances extracts of soils. Environ. Sci. Technol., 42, 3550-3555.

Lipiński W., Terelak H., and Motowicka-Terelak T., 2003. Suggestion for liming values of sulphate sulphur content in mineral soils for fertilization advisory needs (in Polish). Soil Sci. Ann., 54(3), 79-84.

Fan M. and Kuzyakov Y., 2014. Effects of 15 years of manure and mineral fertilizers on enzyme activities in particle-size fractions in a North China Plain soil. Eur. J. Soil Biol., 60, 112-119.

Liu E., Yan Ch., Mei X., He W., Bing S.H. , Ding L., Liu Q., Liu S., and Fan T., 2010. Long-term effect of chemical fertilizer, straw, and manure on soil chemical and biological properties in northwest China. Geoderma, 158, 173-180.

Mazid M., Taqi A.K., and Firoz M., 2011. Response of crop plants under sulphur stress tolerance: A holistic approach. J. S. P. B., 7(3), 23-54.

McLauchlan K., 2006. The Nature and Longevity of Agricultural Impacts on Soil Carbon and Nutrients: A Review. Ecosystems, 9, 1364-1382.

Melero S., Lopez-Bellido R.J., Lopez-Bellido L., Munoz-Romero V., Morenno F., and Murillo J.M., 2011. Long-term of effect of tillage, rotation and nitrogen fertiliser on soil quality in Mediterranean Vertisol. Soil Till. Res., 114, 97-107.

Melero S., Porras J.C.R., Herencia J.F., and Madejon E., 2006. Chemical and biochemical properties in a silty loam soil under conventional and organic management. Soil Till. Res., 90(1-2), 162-170.

Mikha M.M. and Rice C.W., 2004. Tillage and manure effects on soil and aggregate-associated carbon and nitrogen. Soil Sci. Soc. Am. J., 68, 809-816.

Nett L., Averesch S., Ruppel S., Rühlmann J., Feller C., George E., and Fink M., 2010. Does long-term farmyard manure fertilization affect short-term nitrogen mineralization from farmyard manure? Biol. Fert. Soils, 46, 159-167.

Pecio A., Rutkowska A., and Leszczyńska D., 2005. Variability of mineral nitrogen in the soil profile in condition of long - term fertilization experiment. Fragm. Agronom., 22(85), 214-224.

PN-ISO 11261, 2002. Soil quality - Total nitrogen assaying Modified Kjeldahl method.

Sainju U.M., Whitehead W.F., and Wang S., 2006. Carbon supply and storage in tilled and non-tilled soil as influenced by cover crops and nitrogen fertilization. J. Environ. Qual.35, 1507-1517.

Scherer H.W., 2009. Sulfur in soils. J. Plant Nutr. Soil Sci., 172, 326-335. 
Soon Y.K., Arshad M.A., Haq A., and Lupwayi N., 2007. The influence of 12 years of tillage and crop rotation on total and labile organic carbon in a sandy loam soil. Soil Till. Res., 95, 38-46.

Speir T.W., Lee R., Pansier E.A., and Cairns A., 1980. A comparison of sulphatase, urease and protease activities in planted and fallow soils. Soil Biol. Biochem., 1, 79-95.

Tabatabai M.A., 1994. Soil enzymes. In: Methods of Soil Analysis, Part 2. Microbiological and Biochemical Properties (Eds R.W. Weaver, S.H. Mickelson). SSSA Book Series, 5, 814-818.

Varin S., Cliquet J.B., Personeni E., Avice J.C., and LemauvielLavenant S., 2010. How does sulphur availability modify $\mathrm{N}$ acquisition of white clover (Trifolium repens L.)? J. Exp. Bot., 61(1), 225-234.
Vong P.C., Dedourge O., and Guckert A., 2004. Immobilization and mobilization of labelled sulphur in relation to soil arylsulphatase activity in rhizosphere soil of field-grown rape, barley and fallow. Plant Soil, 258, 227-239.

Yang Z., Singh B.R., Hansen S., Hu Z., and Riley H., 2007. Aggregate associated sulfur fractions in long term (>80 years) fertilized soils. Plant Soil, 164, 243-250.

Zhang L., Chen W., Burger M., Yang L., Gong P., and Wu Z., 2015. Changes in soil carbon and enzyme activity as a result of different long-term fertilization regimes in a greenhouse field. PLoS One, 10, 1-13.

Zhao F.J., Knights J.S., Hu Z.Y., and McGrath S.P., 2003. Stable isotope ratio in the Broadbalk experiment since 1845. J. Environ. Qual., 32, 33-39. 